\title{
Development of Sustainable Phycoremediation With the Help of Chlorella Pyrenoidosa for Textile Wastewater Analysis Using Response Surface Methodology
}

\section{Shubhangi Mishra}

IIT BHU: Indian Institute of Technology BHU Varanasi

Pradeep Kumar Srivastava ( $\sim$ pksrivastava.bce@itbhu.ac.in )

IIT BHU: Indian Institute of Technology BHU Varanasi

Virendra Singh

IIT BHU: Indian Institute of Technology BHU Varanasi

Monika Sharma

Banasthali Vidyapith

\section{Research}

Keywords: Bioremediation, Textile wastewater management, Microalgae, River Ganga, Environmental protection, Ecofriendly, Restoration of aesthetic property

Posted Date: October 9th, 2020

DOI: https://doi.org/10.21203/rs.3.rs-87566/v1

License: (c) (i) This work is licensed under a Creative Commons Attribution 4.0 International License. Read Full License 


\section{Abstract}

The uncontrolled utilization for the textile products is increasing year by year resulting with the elevating wastewater generated from the textile industries, which makes it among the prevalent sources of critical environmental deteoration issue globally. Products obtained from the dyes used are the primary toxic product for aquatic life, they cause aesthetic pollution, eutrophication, perturbation and increase in BOD and COD in aquatic life. Three types of textile wastewaters (Acid Yellow dye, Acid orange dye and Basic pink dye) has been used for wastewater treatment and microalgal (Chlorella pyrenoidosa) biomass production. Nitrogen content in textile wastewaters is very less, hence urea is used as nitrogen source in wastewater. Optimal growth condition (Urea- $0.4 \mathrm{~g} / \mathrm{L}$, wastewater- $40 \%(\mathrm{v} / \mathrm{v})$ ) is developed through Response surface methodology (RSM). The biomass productivity for chlorella sp. is $1.2-1.5 \mathrm{~g} / \mathrm{L} /$ day in textile wastewaters. The reduction efficiency of COD, Nitrate-N Ammonia-N, Phosphate-P, and Dye(color) removal for Chlorella is $90-95 \%, 75-85 \%$, $90-98 \%, 65-74 \%$ and $40-65 \%$.After harvesting the Biomass by flocculation method it can be used for biofuel production by in-situ transesterification.

\section{Introduction}

Water pollutants may originate from point sources or from dispersed sources. Point-source pollutants are easier to control than dispersed-source pollutants, since they flow to a single location where treatment processes can remove them from the water. Such control is not usually possible over pollutants from dispersed sources, which cause a large part of the overall water pollution problem. Dispersed-source water pollution is best reduced by enforcing proper landuse plans and development standards. Excessive reactive oxygen species, would be produced by the algal cells which would cause cellular peroxidation, in this manner chloroplasts being destroyed, inhibiting chlorophyll synthesis and hence dropping photosynthesis. With increasing the time of exposure, irreversible algal damage may lead to death [1]. Significance of treatment of wastewater should be marked as a water use as it is interconnected with the other uses of water. Mass cultivation is the most critical step in terms of water and nutrient requirement. Wastewater from industries such as textile wastewater (TWW) is source for water which is easily available,cheap and additionally encompasses obligatory nutrients (nitrates, phosphate, micronutrients etc.) and organic dyes (potential carbon source) for cultivation of algae[2].

There are a number of textile industries which are dumping their wastewater untreated into the environment which are not only toxic but also changing the BOD COD levels and hence the entire physiochemical parametric texture. Many types of chemical dye used in textile industries are very harmful to the aquatic life and fish species. Most of the dyes have carcinogenic action and also cause other skin problems like allergies, dermatitis, skin irritation, etc [3]. The textile wastewater holds a typical characteristic of strong order high chemical oxygen demand (COD) high salinity variable $\mathrm{PH}$ and elevated temperature [4]. Coloured dyes in the wastewater adversely affect aesthetics, gas solubility, transparency of water and can equally prove to be hazardous to both aquatic flora and fauna resulting with critical environmental issues. Also, to be included that most synthetic azodyes and their metabolites are mutagenic and carcinogenic potent enough to be toxic to human health to be toxic to human health. The process of treatment of the textile effluents includes mainly physical and chemical ways, but they cost expensive. It becomes difficult to treat the dye wastewater by physical and chemical due to their complicated molecular structures. Not only this has the disposal of thickened sludge generated a bigger problem using biological methods for textile wastewater remediation is gaining interest now. Majority of the studies are focusing on the application of bacteria, algae and fungi to check coloured wastewater from the textile [5]. The research areas using microalgae in phytoremediation of coloured textile wastewater is gaining attention because of their significant role and fixation of carbon dioxide, in addition it can be sustainably and economically used for production of biofuel[6]. In this research an attempt is to use a microalgae named Chlorella pyrenoidosa for treatment of wastewater using a complete in-situ eco-friendly operation on a low cost self - designed tubular photobioreactor. Although, many studies have been done earlier by different researchers earlier, an innovative approach 
of cost effectiveness to pilot technology is referred, yet an attempt is made for people, so that it becomes accessible and afforadable not only for the large scale industrialists on a large scale and the small scale textile manufacturers, to check before discharging the untreated wastewater which is extremely toxic not only for the environment but also for the Ganga inhabitants and people using the gangawater by any means.

The purpose of the study is to design and evaluate a sustainable way of bioremediation using Chlorella pyrenoidosa and analysis of pollutant removal from textile wastewater, making the technology accessible on a larger scale.

\section{Materials And Methods}

\subsection{Culture Preparation}

The microalgae strain Chlorella pyrenoidosa (NCIM Accession number 2738), was collected from National Chemical Laboratory, Council of Scientific Research, Pune, India. 10\% (v/v) of inoculums of exponentially growing algae culture is used for the biomass growth and optimization. Along with the parametric studies which are designed for the characterization and defining optimal operating requirements for Chlorella pyrenoidosa as mass culture [7], also monometric studies were implemented to study if the pollutants could significantly reduce the 02-CO2 efficiency for gasexchange of the Chlorella.

A reformed Trypticase-glucose-yeast extract (TGYE) medium comprising $5.0 \mathrm{~g}$ of Tryptone-phytone, $1 \mathrm{~g}$ of yeast extract, $2.5 \mathrm{~g}$ of glucose and $15 \mathrm{~g}$ of agar per liter of distilled water were used as the plating medium.Followed by which the samples were withdrawn from the photosynthetic gas-exchange unit when the steady state of growth were observed by the algal culture. All plates were counted after $24 \mathrm{hr}$ of incubation at $39 \mathrm{C}$.

\subsection{Sample Collection (textile wastewater) and characterization}

The effluents as wastewater were taken from textile industries and their outlets into the river Ganga in Varanasi using the Grab Sampling method. Textile wastewater contains many dyes which affects the aquatic system. Three types textile dyes are collected named as Acid yellow 17 dye, Acid orange 7 dye and Basic pink dye containing textile wastewater. The Characterization of physical and chemical parameters and biological parameters like Titerimetric method for COD, Wrinkler method for BOD, Nesslers method for Nitrogen estimation of each batch sample collected was determined using standard protocols (APHA).

\subsection{Experimental Studies}

Three textile azo dyes were used in the research investigation, named as Acid yellow, Acid orange, Basic pink. To determine the wavelength giving a maximum absorption, the absorbance of these three dyes were examined from 300 to 700 nanometers using a spectrophotometer (Shimadzu UV/Vis 160). Acid yellow (AY) is an acidic dye with absorption maximum at $650 \mathrm{~nm}$ while acid orange (AO) is another acidic dye with maximum absorption at $670 \mathrm{~nm}$ whereas basic pink (BP) is a basic dye with absorption maximum at $580 \mathrm{~nm}$.

\subsection{Physiochemical Parameters}

Titrimetric method is used for COD studies. Prior to completing the COD test, a series of known standards are prepared using KHP (potassium hydrogen phthalate). Most wastewater samples will fall in the high range, so standards of 100 , 250,500 and $1000 \mathrm{mg} / \mathrm{L}$ are typically prepared. COD standards can also be purchased. A COD reactor/heating $\left(150{ }^{\circ} \mathrm{C}\right)$ block and a colorimeter are turned on so that both instruments are allowed to stabilize.

Pre-prepared low-range (3-50 ppm) or high-range $(20-1500 \mathrm{ppm})$ vials are selected for the COD test based on expected results. Both ranges can be used if expected results are unknown. 
One vial is marked as a "blank," and three or four vials are marked with known standard levels. Two vials are then marked for the wastewater sample to make a duplicate run. Note: If multiple wastewater samples are being run, at least $10 \%$ of samples are duplicated.

$2 \mathrm{~mL}$ of liquid are added to each vial. In the case of the "blank," $2 \mathrm{~mL}$ of DI water are added. $2 \mathrm{~mL}$ of each standard are added to the corresponding vials. If the wastewater sample is tested at full strength, then $2 \mathrm{~mL}$ is added to the corresponding vial. If dilution is required, then serial dilutions are performed and $2 \mathrm{~mL}$ of the diluted sample are added to the corresponding vial.

Each vial is mixed well and placed into the reactor block for two hours. After two hours, the vials are removed from the block to a cooling rack for about 15 minutes.

The colorimeter is set and calibrated per the specific instructions for that unit (i.e., proper wavelength, blank and standards) and each vial is placed in the unit and the COD concentration read. If the sample was diluted, the corresponding multiplication is made.

Winkler method for BOD and DO studies, the method involves filling a sample bottle completely with water (no air is left to bias the test). The dissolved oxygen is then "fixed" using a series of reagents that form an acid compound that is titrated. Titration involves the drop-by-drop addition of a reagent that neutralizes the acid compound and causes a change in the color of the solution. The point at which the color changes is the "endpoint" and is equivalent to the amount of oxygen dissolved in the sample.

Nessler method for Nitrogen estimation studies, In the ammonia test, Nessler Reagent (K2Hgl4) reacts with the ammonia present in the sample (under strongly alkaline conditions) to produce a yellow-colored species. The intensity of the color is in direct proportion to the ammonia concentration.

\subsection{Microalgae strain and growth optimization}

Shake flask study has been performed in inoculum in wastewater sample, samples were taken daily in 2 ml volumes from each shaker flask and analyzedfor soluble $\mathrm{N}$ for 10 to 20 days and was used to determine the 'algal growth rate ( $k$ )

Experimental Setup - A Photobioreactor ( made of perspex ) of volume of $10.5 \mathrm{~L}$, which was in continuous illumination by tubular fluorescent lamps (40W PHILIPS tube lights). The light intensity kept 5400lux at the surface of culturing vessels so that the growth of microalgae can be maximum. The culture medium of textile effluent is diluted and divided in to runs according to the factorial design to calculate the optimum growth condition. The microalgal cells were inoculated with a concentration of $20 \%$ ( $V$ of inoculation/ $\mathrm{V}$ of solvent) in a $10.8 \mathrm{~L}$ reactor incubated at room temperature with a 16/8-hour dark/light period for 8 days and optical density was recorded per day.

\subsection{Cell Mass Extraction}

After the treatment of wastewater in the PBR biomass is harvested with the flocculation technique. The characterization of chemical, physical and biological parameter of every batch sample collected was analyzed performing the standard protocols (APHA). The major nitrogen and carbon elimination processing in the algal photobioreactor were assimilation into biomass (algal) and stripping ahead.

As soon as growth in algae was noticed and it started multiplying, both phosphorus and nitrogen content in wastewater decreased significantly. There was a rapid removal rate reported during the first week of growth and more than of wastewater $\mathrm{N}$ and $\mathrm{P}$ was reduced. However, post the initial period, the removal rate slowed down. At the end of this study, more than $80 \%$ of total inorganic Nitrogen and Phosphorus removal was observed. At large, a higher inoculum 
size of algal cells provided more phosphorus and nitrogen removal than that in the lower inoculum. The findings suggest that of Chlorella cultivation seems to be one of the viable approaches to decrease the amount of phosphorus and nitrogen entering the nearby shoreline water, thus checking the eutrophication problem. Also to be noticed, that algal ponds with higher inoculum size might be more suitable to be installed as a secondary process comparative to a tertiary treatment.

\section{Results And Discussion}

\subsection{Textile wastewater characterization}

The Physico-chemical characterization of textile wastewaters was done by the standard protocol given in APHA manual. Sample was collected with method of discrete sampling at different location from Textile industry in or near Varanasi, India. The result of textile wastewater characterization conferred in Table 1 indicates that values of pH, colour, temperature, total dissolved solid (TDS), total suspended solid (TSS), alkalinity (Carbonate), total nitrogen(ammonia), total nitrogen (Nitrate), total Phosphorus, Biological oxygen demand (BOD), Dissolved oxygen(DO) and Chemical oxygen demand (COD). BOD content is high $(67.2 \mathrm{mg} / \mathrm{L})$ in the case of acid orange textile wastewater and in all the textile dyes the nitrogen content (ammonia + nitrate) is low. Table 3 shows that the values of pH, TSS, TDS, Nitrogen (ammonia) and Phosphorus (phosphate) found for acid yellow wastewater used in this study were 8.1, $63 \mathrm{mg} / \mathrm{L}, 120 \mathrm{mg} / \mathrm{L}, 0.32 \mathrm{mg} / \mathrm{L}$ and $1.4 \mathrm{mg} / \mathrm{L}$. However, COD and BOD are $296 \mathrm{mg} / \mathrm{L}$ and $28.8 \mathrm{mg} / \mathrm{L}$ respectively. The values of $\mathrm{pH}, \mathrm{TSS}, \mathrm{TDS}$, Nitrogen (ammonia) and Phosphorus (phosphate) obtained for acid yellow wastewater used in this study were 8.2, $74 \mathrm{mg} / \mathrm{L}$, $132 \mathrm{mg} / \mathrm{L}, 0.18 \mathrm{mg} / \mathrm{L}$ and $3.8 \mathrm{mg} / \mathrm{L}$. However, COD and BOD are $288 \mathrm{mg} / \mathrm{L}$ and $33.6 \mathrm{mg} / \mathrm{L}$ respectively. The values of $\mathrm{pH}, \mathrm{TSS}, \mathrm{TDS}$, Nitrogen (ammonia) and Phosphorus (phosphate) obtained for acid orange wastewater used in this study were 8.1, $43 \mathrm{mg} / \mathrm{L}, 135 \mathrm{mg} / \mathrm{L}, 0.38 \mathrm{mg} / \mathrm{L}$ and $2.3 \mathrm{mg} / \mathrm{L}$. However, COD and BOD are $272 \mathrm{mg} / \mathrm{L}$ and 67.2 mg/L respectively.

Table 1: Physicochemical characterization of textile wastewater (Acid Yellow, Acid Orange and Basic pink dye).

\begin{tabular}{|lllll|}
\hline S.N. & Parameter & Acid Yellow 17 dye & Acid Orange 7 Dye & Basic Pink Dye \\
\hline 1. & Colour(660nm) & Yellow $(0.024)$ & Orange $(0.032)$ & Dark Pink (0.045) \\
\hline 2. & $\mathrm{pH}$ & 8.1 & 8.1 & 8.2 \\
\hline 3. & Temperature & $35^{0} \mathrm{C}$ & $35^{0} \mathrm{C}$ & $38^{0} \mathrm{C}$ \\
\hline 4. & Total suspended solids & $63 \mathrm{mg} / \mathrm{L}$ & $43 \mathrm{mg} / \mathrm{L}$ & $74 \mathrm{mg} / \mathrm{L}$ \\
\hline 5. & Total dissolved solids & $120 \mathrm{mg} / \mathrm{L}$ & $135 \mathrm{mg} / \mathrm{L}$ & $132 \mathrm{mg} / \mathrm{L}$ \\
\hline 6. & Alkalinity(carbonate) & $69.6 \mathrm{mg} / \mathrm{L}$ & $52.8 \mathrm{mg} / \mathrm{L}$ & $76.8 \mathrm{mg} / \mathrm{L}$ \\
\hline 7. & Nitrogen (ammonia) & $0.32 \mathrm{mg} / \mathrm{L}$ & $0.38 \mathrm{mg} / \mathrm{L}$ & $0.18 \mathrm{mg} / \mathrm{L}$ \\
\hline 8. & Nitrogen (Nitrate) & $0.85 \mathrm{mg} / \mathrm{L}$ & $0.12 \mathrm{mg} / \mathrm{L}$ & $0.225 \mathrm{mg} / \mathrm{L}$ \\
\hline 9. & Phosphate & $1.4 \mathrm{mg} / \mathrm{L}$ & $2.3 \mathrm{mg} / \mathrm{L}$ & $3.8 \mathrm{mg} / \mathrm{L}$ \\
\hline 10. & Dissolved oxygen & $10.8 \mathrm{mg} / \mathrm{L}$ & $16 \mathrm{mg} / \mathrm{L}$ & $12.8 \mathrm{mg} / \mathrm{L}$ \\
\hline 11. & BOD & $28.8 \mathrm{mg} / \mathrm{L}$ & $67.2 \mathrm{mg} / \mathrm{L}$ & $33.6 \mathrm{mg} / \mathrm{L}$ \\
\hline 12. & COD & $296 \mathrm{mg} / \mathrm{L}$ & $272 \mathrm{mg} / \mathrm{L}$ & $288 \mathrm{mg} / \mathrm{L}$ \\
\hline
\end{tabular}


Table 2: RSM table of Raw Material optimization for Chlorella Pyrenoidosa 


\begin{tabular}{|c|c|c|c|c|c|c|c|c|}
\hline & $\begin{array}{l}\text { Factor } \\
1\end{array}$ & Factor 2 & Factor 3 & Factor 4 & Response 1 & $\begin{array}{l}\text { Response } \\
2\end{array}$ & $\begin{array}{l}\text { Response } \\
3\end{array}$ & Response 4 \\
\hline Run & A:pH & $\begin{array}{l}\text { B:Carbon } \\
\text { Source }\end{array}$ & $\begin{array}{l}\text { C:Nitrogen } \\
\text { Source }\end{array}$ & D:Wastewater\% & $\begin{array}{l}\text { Biomass } \\
\text { Productivity }\end{array}$ & $\begin{array}{l}\text { Colour } \\
\text { Removal }\end{array}$ & $\begin{array}{l}\text { Nitrogen } \\
\text { Removal }\end{array}$ & $\begin{array}{l}\text { Phosphorus } \\
\text { removal }\end{array}$ \\
\hline & & $g / L$ & $g / L$ & & g/L/day & $\%$ & $\%$ & $\%$ \\
\hline 1 & 5 & 0.4 & 0.2 & 20 & 0.58 & 41 & 71 & 42 \\
\hline 2 & 11 & 0.4 & 0.2 & 20 & 0.61 & 42 & 72 & 44 \\
\hline 3 & 8 & 0.3 & 0.65 & 40 & 0.89 & 60 & 88 & 59 \\
\hline 4 & 5 & 0.2 & 0.2 & 20 & 0.66 & 48 & 75 & 48 \\
\hline 5 & 5 & 0.4 & 0.5 & 60 & 0.78 & 58 & 85 & 59 \\
\hline 6 & 5 & 0.4 & 0.5 & 20 & 0.98 & 62 & 89 & 63 \\
\hline 7 & 2 & 0.3 & 0.35 & 40 & 0.41 & 42 & 70 & 45 \\
\hline 8 & 5 & 0.2 & 0.2 & 60 & 0.64 & 51 & 79 & 53 \\
\hline 9 & 8 & 0.3 & 0.05 & 40 & 0.86 & 54 & 80 & 52 \\
\hline 10 & 14 & 0.3 & 0.35 & 40 & 0.38 & 35 & 60 & 36 \\
\hline 11 & 8 & 0.3 & 0.35 & 40 & 1.2 & 72 & 98 & 70 \\
\hline 12 & 8 & 0.3 & 0.35 & 0 & 0.19 & 30 & 60 & 29 \\
\hline 13 & 11 & 0.2 & 0.5 & 20 & 0.52 & 46 & 73 & 47 \\
\hline 14 & 8 & 0.3 & 0.35 & 40 & 1.34 & 69 & 95 & 70 \\
\hline 15 & 5 & 0.2 & 0.5 & 60 & 0.59 & 45 & 71 & 44 \\
\hline 16 & 11 & 0.4 & 0.2 & 60 & 0.66 & 48 & 70 & 47 \\
\hline 17 & 11 & 0.2 & 0.2 & 20 & 0.71 & 51 & 80 & 54 \\
\hline 18 & 5 & 0.2 & 0.5 & 20 & 0.65 & 48 & 73 & 48 \\
\hline 19 & 11 & 0.2 & 0.5 & 60 & 0.59 & 44 & 71 & 44 \\
\hline 20 & 11 & 0.4 & 0.5 & 60 & 0.56 & 43 & 69 & 43 \\
\hline 21 & 8 & 0.5 & 0.35 & 40 & 0.99 & 65 & 91 & 66 \\
\hline 22 & 8 & 0.3 & 0.35 & 40 & 1.1 & 69 & 94 & 70 \\
\hline 23 & 8 & 0.1 & 0.35 & 40 & 0.7 & 64 & 92 & 62 \\
\hline 24 & 8 & 0.3 & 0.35 & 40 & 1.26 & 68 & 95 & 69 \\
\hline 25 & 5 & 0.4 & 0.2 & 60 & 0.66 & 49 & 76 & 50 \\
\hline 26 & 11 & 0.2 & 0.2 & 60 & 0.65 & 48 & 74 & 51 \\
\hline 27 & 8 & 0.3 & 0.35 & 80 & 0.59 & 43 & 71 & 45 \\
\hline 28 & 11 & 0.4 & 0.5 & 20 & 0.56 & 41 & 69 & 40 \\
\hline 29 & 8 & 0.3 & 0.35 & 40 & 0.98 & 64 & 91 & 65 \\
\hline
\end{tabular}


Table 3: Removal efficiency of pollutant in three types of textile

\begin{tabular}{|llll|}
\hline Parameter & Removal Efficiency in Acid Yellow dye (\%) & $\begin{array}{l}\text { Removal Efficiency in } \\
\text { Acid Orange Dye (\%) }\end{array}$ & $\begin{array}{l}\text { Removal Efficiency in } \\
\text { Basic Pink Dye (\%) }\end{array}$ \\
\hline Nitrogen (ammonia) & $91 \pm 3 \%$ & $90 \pm 3 \%$ & $91 \pm 1 \%$ \\
\hline Phosphate & $65 \pm 2 \%$ & $60 \pm 1 \%$ & $63 \pm 1 \%$ \\
\hline COD & $91 \pm 1 \%$ & $94 \pm 2 \%$ & $90 \pm 2 \%$ \\
\hline Color removal & $65 \pm 2 \%$ & $59 \pm 5 \%$ & $55 \pm 5 \%$ \\
\hline
\end{tabular}

\subsection{Microalgae growth optimization and Kinetics Study}

The microalgae culture was inoculated in the shake flask $(250 \mathrm{ml})$ under light control for 10 days and allowed for the growth in Batch Mode operation, after that the growth and Biomass content is calculated. The graph of 2(a) shows the growth kinetics curve for the Chlorella pyrenoidosa, the results obtained by cultivating the Chlorella pyrenoidosa in the Bolds basal media (BBM). Lag phase occurred for 3 days and log phase occurred for 7 days for the Chlorella pyrenoidosa. The growth constant $(\mu)$ is $0.21 \mathrm{~g} / \mathrm{L} /$ day and maximum growth rate constant ( $\mu$ max) is $0.29 \mathrm{~g} / \mathrm{L} /$ day.

Growth curve (Fig. 2(b)) of Chlorella pyrenoidosa in Acid yellow 17 dye, Acid orange 7 dye and Basic pink dye textile wastewater in composition of $10 \%$ of wastewater and BBM $90 \%$, the biomass productivity is $0.98 \pm 0.3 \mathrm{~g} / \mathrm{L} / \mathrm{day}, 0.96 \pm$ $0.2 \mathrm{~g} / \mathrm{L} /$ day, $1.2 \pm 0.3 \mathrm{~g} / \mathrm{L} /$ day respectively. As the nitrogen content is textile wastewaters is very low and the for the microalgae growth nitrogen content is very important, hence different types of nitrogen source is used like sodium Nitrate $\left(\mathrm{NaNO}_{3}\right)$, ammonium nitrate $(\mathrm{NH} 4 \mathrm{NO} 3)$, ammonium chloride $\left(\mathrm{NH}_{4} \mathrm{Cl}\right)$ and urea $\left(\mathrm{NH}_{2} \mathrm{CONH}_{2}\right)$ in the concentration $0.2 \mathrm{~g} / \mathrm{L}, 0.4 \mathrm{~g} / \mathrm{L}, 0.4 \mathrm{~g} / \mathrm{L}$ and $0.2 \mathrm{~g} / \mathrm{L}$ respectively. The biomass productivity is $0.75 \pm 0.2 \mathrm{~g} / \mathrm{l} /$ day in all the sources showed in Fig. 2(c). Hence nitrogen content is enriched by urea. Urea is low cost source having the high biomass productivity. The physicochemical characteristics of textile wastewater is highly fluctuating but it is comparable and within range as reported [8]. However, the components of textile wastewaters vary as per the raw materials and ingredients used in textile manufacturing. Nitrogen (Ammonia) and Nitrogen (Nitrate) in textile wastewaters are generally low, hence external nitrogen source is required. Low Nitrogen content has an added advantage as it enhances the lipid productivity in the Microalga biomass but low nitrogen content also affects the growth of microalgae. The urea is best nitrogen source for the textile wastewater as it is cheap and easily available. The maximum biomass density $0.79 \mathrm{~g} / \mathrm{l} /$ day found in the case of Ammonium nitrate $\left(\mathrm{NH}_{4} \mathrm{NO}_{3}\right)$. Similarly, the carbon source is also optimized using different carbon source like Sodium carbonate $\left(\mathrm{Na}_{2} \mathrm{CO}_{3}\right)$, Sodium bi-carbonate $\left(\mathrm{NaHO}_{3}\right)$, and Potassium Bi-carbonate $\left(\mathrm{KHO}_{3}\right)$, the biomass productivity is $0.4 \pm 0.1,0.2 \pm 0.05,0.2 \pm 0.05 \mathrm{~g} / \mathrm{L} /$ day respectively. The maximum biomass productivity found in the case of sodium carbonate (Fig. 2(d)).

The biomass concentration of algae reaches to approximately $6 \mathrm{~g} / \mathrm{l}$ by around 8 th day after having a lag phase of 2 days from the day of inoculation in BBM while in the textile wastewaters (Acid yellow, Acid orange and Basic pink) when inoculated by the acclimatized algal species operated for 10 days monitoring the algal growth, in $20 \%$ dyes mixed with $10 \% \mathrm{BBM}$, the graph elevated to maximum of around $1 \mathrm{~g} / \mathrm{l}$ biomass concentration on 8th day for pink dye treatment and 
around $10 \mathrm{~g} / \mathrm{l}$ biomass concentration on around 8th day of yellow and orange dye which shows a significant increase in growth compared to BBM only. Biomass concentrations were optimized by various nitrogen sources where a number of nitrogen sources were exposed with algae for comparative analysis. The biomass concentrations were found increasing with $\mathrm{NH}_{4} \mathrm{NO}_{3}$ in comparison to $\mathrm{NaNO}_{3}, \mathrm{NH}_{4} \mathrm{Cl}$ and Urea but it was interesting to find out that Urea which did not show rise in graph initially (lag phase is long) but showed significant growth during log phase, not only this Urea is found to be the most cheapest Nitrogen source to be used (around $10 \mathrm{Rs} / \mathrm{kg}$ ) and very easily available. Amongst the various Carbon sources used for optimization, Sodium bicarbonate was found showing maximum biomass concentration $3.5 \mathrm{~g} / \mathrm{l}$ on 5 th day which was considerably higher with respect to Sodium Carbonate and Potassium bicarbonate with biomass concentration of $2 \mathrm{~g} / \mathrm{l}$ on 5 th and 6th day respectively.

\subsection{Statistical Optimization Study}

ANOVA model is calculated for biomass productivity, The Model F-value of 9.68 implies the model is significant. Pvalues estimated 0.0001 which is not as much as 0.0500 designate significance of model terms. Relative to the pure error, the Lack of Fit F-value of 0.50 implies that Lack of Fit is not significant. The Predicted $R^{2}$ of 0.6404 is in realistic agreement with the adjusted $\mathrm{R}^{2}$ of 0.8073 ; i.e. the alteration is a reduced amount from 0.2 . Precision measures the signal to noise ratio. It is desirable to get a ratio greater than 4. The obtained proportion of 9.623 specifies a signal which is adequate. ANOVA model is calculated for colour removal, the Model F-value of 20.64 indicates the model is significant. P-values found $\mathbf{0 . 0 0 0 1}$ which is a lesser amount of 0.0500 point towards the significance of model terms. Relative to the pure error the Lack of Fit F-value of 1.98 indicates the Lack of Fit is not significant. The Predicted $\mathrm{R}^{2}$ of 0.7561 is in reasonable agreement with the Adjusted $\mathrm{R}^{2}$ of 0.9035 ; i.e. the difference is less than 0.2 . Adeq Precision measures the signal to noise ratio. A ratio greater than 4 is desirable. The obtained ratio of 14.205 indicates an adequate signal. ANOVA is calculated for Nitrogen removal, The Model F-value of 17.25 suggests the significance of the model. P-values calculated 0.0001 which is a smaller amount than 0.0500 indicates the significance of model terms. Relative to the pure error the Lack of Fit F-value of 3.02 indicates that the Lack of Fit is not significant. The Predicted $\mathrm{R}^{2}$ of 0.6991 is in rational agreement with the Adjusted $\mathrm{R}^{2}$ of 0.9035 ; i.e. the variance is less than 0.2. Adeq Precision processes the signal to noise ratio. A ratio more than 4 is desirable. The obtained proportion of 13.65 designates signal which is adequate. ANOVA is calculated for Phosphorus removal, The Model F-value of 16.87 infers the model is significant. The significance of the model terms is indicated by P-values found 0.0001 which is less than 0.0500 . Relative to the pure error the Lack of Fit F-value of 3.67 implies the Lack of Fit is not significant. The Predicted $R^{2}$ of 0.7561 is in judicious agreement with the Adjusted $\mathrm{R}^{2}$ of 0.69 ; i.e. the variance is less than 0.2 . Adeq Precision processes the signal to noise ratio. A ratio heigher than 4 is desirable. The obtained proportion of 13.02 indicates an adequate signal.

Then optimized value for various parameter like $\mathrm{pH}$, carbon source, Nitrogen source and wastewater \% used for the biomass productivity, colour removal, Nitrogen removal, and Phosphorus removal are 8.431 $\pm 0.6,0.29 \pm 0.1 \mathrm{~g} / \mathrm{L}, 0.2 \pm$ $0.05 \mathrm{~g} / \mathrm{L}$ and $38.90 \pm 5 \%$ respectively. Obtained optimized results for biomass productivity, colour removal, Nitrogen removal, Phosphorus removal are $1.13 \pm 0.2 \mathrm{~g} / \mathrm{L} / \mathrm{Day}, 65 \pm 2 \%, 91 \pm 3 \%, 65 \pm 1 \%$ respectively as given the figure( 3 ).

Surface plots obtained from the RSM optimization for biomass productivity with correlation effect of Carbon source and $\mathrm{pH}$, Nitrogen Source and pH, wastewater\% and pH, Carbon Source and Nitrogen Source, wastewater\% and Carbon source and Wastewater\% and Nitrogen source are represented in the figure (4). The optimized value of $\mathrm{pH}$, carbon source, Nitrogen source and wastewater \% are $8.431 \pm 0.6,0.29 \pm 0.1 \mathrm{~g} / \mathrm{L}, 0.2 \pm 0.05 \mathrm{~g} / \mathrm{L}$ and $38.90 \pm 5 \%$ respectively.

Surface plots obtained from the RSM optimization for Colour removal efficiency\% with correlation effect of Carbon source and pH, Nitrogen Source and pH, wastewater\% and pH, Carbon Source and Nitrogen Source, wastewater\% and Carbon source and Wastewater\% and Nitrogen source are represented in the figure (5). The optimized value of $\mathrm{pH}$, carbon source, Nitrogen source and wastewater \% are $8.431 \pm 0.6,0.29 \pm 0.1 \mathrm{~g} / \mathrm{L}, 0.2 \pm 0.05 \mathrm{~g} / \mathrm{L}$ and $38.90 \pm 5 \%$ respectively. 
Surface plots obtained from the RSM optimization for Nitrogen removal efficiency \% with correlation effect of Carbon source and pH, Nitrogen Source and pH, wastewater\% and pH, Carbon Source and Nitrogen Source, wastewater\% and Carbon source and Wastewater\% and Nitrogen source are represented in the figure (6). The optimized value of $\mathrm{pH}$, carbon source, Nitrogen source and wastewater \% are $8.431 \pm 0.6,0.29 \pm 0.1 \mathrm{~g} / \mathrm{L}, 0.2 \pm 0.05 \mathrm{~g} / \mathrm{L}$ and $38.90 \pm 5 \%$

Surface plots obtained from the RSM optimization for Phosphorus removal efficiency \% with correlation effect of Carbon source and pH, Nitrogen Source and pH, wastewater\% and pH, Carbon Source and Nitrogen Source, wastewater\% and Carbon source and Wastewater\% and Nitrogen source are represented in the figure (7).

The optimized value of $\mathrm{pH}$, carbon source, Nitrogen source and wastewater \% are $8.431 \pm 0.6,0.29 \pm 0.1 \mathrm{~g} / \mathrm{L}, 0.2 \pm$ $0.05 \mathrm{~g} / \mathrm{L}$ and $38.90 \pm 5 \%$ respectively.

\subsection{Analysis of pollutant removal}

Potential of microalgae in degrading specific pollutants are being studied. Microalgae has been reported for degradation of large number of micropollutants, p-chlorophenol collected from a site where water contaminated with a number of aromatic pollutants can be degraded at a rate of $10 \mathrm{mg} / \mathrm{L} /$ day by Chlorella vulgaris and Coenochloris pyrenoidosa[9].

The analysis of parameters including COD, ammonia, colour and phosphorus were examined with respect to the methodology described in APHA (2000) at the beginning as well as at the end of the run. The composition contained by textile wastewater are found to be complicated containing heavy metals [10], dyes, salts [11] and reagents [12]. Many procedures have been employed absorption with activated carbon, ion exchange, electrochemical destruction, and filtration by membrane, ozonation and irradiation [13]. Cultivation of algae in textile effluents uses carbon, nitrogen and phosphorous and other nutrients for its growth. During the process of bioconversion, the microalgae uses dyes and $\mathrm{CO} 2$ as their carbon sources and finally transform them into metabolites moreover these algae can equally be employed as bio sorbent as the dyes hold the potential to absorb onto their surface.

As can be seen in the graph shown in Fig. 8 (a) COD concentration was ranging from 250-300 mg/L for all the three dyes i.e. acid yellow, acid orange and basic pink on day 0 but as the growth continues a steady fall in the graph can be seen, as soon as it reaches the 8th day the COD level drops down to $50 \mathrm{mg} / \mathrm{L}$ which shows that Chlorella pyrenoidosa is efficient enough to remove COD. On the contrary when the same study was performed with phosphorus, the level of phosphorus in acid yellow and acid orange was around $2.5 \mathrm{mg} / \mathrm{L}$ while in basic pink it was around $4.0 \mathrm{mg} / \mathrm{L}$ way higher than the other two but as the growth reaches between 4 to 6 days the graph falls down to $1.0 \mathrm{mg} / \mathrm{L}$ which confirms the efficiency of the alga in removing phosphorus as can be seen in Fig. 8 (b). Figure 8 (c) shows removal of ammonia where the level for the three dyes having ammonia were as high as 14-16 mg/L which experiences a steep fall in the graph and falls down to $2 \mathrm{mg} / \mathrm{L}$ at around 8th day of inoculation. The removal of colour was studied for the three dyes which were ranging from 0.09 to 0.10 on the day 0 but the intensity of colour was significantly decreased to the level of 0.05 on the fifth day and fell down to 0.04 on the 9 th day of inoculation confirming the ability of Chlorella pyrenoidosa in removing colour of the dyes successfully.

The efficiency of nitrogen (ammonia) removal, Nitrogen (nitrate) removal, COD removal, colour removal, and phosphorus removal in three types textile wastewaters (acid yellow dye containing textile wastewater, acid orange dye containing textile wastewater, basic pink dye containing textile wastewater) is explained in the form of bar chart given in figure (9).

A very little variation in nitrogen (ammonia) removal efficiency in acid yellow dye containing textile wastewater (91 \pm $3 \%$ ), acid orange dye containing textile wastewater (90 $\pm 3 \%$ ), and basic pink dye containing textile wastewater (91 $\pm 1 \%)$. A small variation found in nitrogen (Nitrate) removal efficiency in acid yellow dye containing textile wastewater (79 \pm $2 \%)$, acid orange dye containing textile wastewater (68 $\pm 3 \%)$, and basic pink dye containing textile wastewater $(70 \pm 4 \%)$. 
A very little or negligible variation in Phosphate removal reported, efficiency in acid yellow dye containing textile wastewater $(65 \pm 2 \%)$, acid orange dye containing textile wastewater $(60 \pm 1 \%)$, and basic pink dye containing textile wastewater $(63 \pm 1 \%)$. However a minor variation in COD removal efficiency in acid yellow dye containing textile wastewater $(91 \pm 1 \%)$, acid orange dye containing textile wastewater $(94 \pm 2 \%)$, and basic pink dye containing textile wastewater $(90 \pm 2 \%)$. A small decrease observed in color removal efficiency in acid yellow dye containing textile wastewater $(65 \pm 2 \%)$, acid orange dye containing textile wastewater $(59 \pm 5 \%)$, and basic pink dye containing textile wastewater $(55 \pm 5 \%)$ respectively.

The efficiency of nitrogen (ammonia) removal, Nitrogen (nitrate) removal, COD removal, colour removal, and phosphorus removal in three types textile wastewaters (acid yellow dye containing textile wastewater, acid orange dye containing textile wastewater, basic pink dye containing textile wastewater) is explained in the form of bar chart given in Table (3).

\section{Conclusions}

Three types of textile wastewater were used for the study containing the Acid yellow, Acid orange and Basic Pink dye. The growth of microalgae species Chlorella pyrenoidosa was low initially $0.3-0.4 \mathrm{~g} / \mathrm{L} / \mathrm{day}$ but after acclimatization biomass productivity increased up to 1.2-1.5 g/L/Day in textile dyes. Nitrogen content in all type textile wastewaters was very less, hence urea is used as nitrogen source in wastewater. Then optimized value for various parameter like $\mathrm{pH}$, carbon source, Nitrogen source and wastewater \% used for the biomass productivity, colour removal, Nitrogen removal, and Phosphorus removal are $8.431 \pm 0.6,0.29 \pm 0.1 \mathrm{~g} / \mathrm{L}, 0.2 \pm 0.05 \mathrm{~g} / \mathrm{L}$ and $38.90 \pm 5 \%$ respectively. Obtained optimized results for biomass productivity, colour removal, Nitrogen removal, Phosphorus removal are $1.13 \pm 0.2 \mathrm{~g} / \mathrm{L} / \mathrm{Day}, 65 \pm 2 \%$,

$91 \pm 3 \%, 65 \pm 1 \%$ respectively. The COD removal efficiency obtained $92 \pm 1 \%$ in nearly all three types of textile wastewater. Harvesting (flocculation method) is optimized using RSM in which chitosan was used as flocculant. The optimum condition achieved for flocculation is $0.5 \mathrm{~g} / \mathrm{l}$ at pH 10.0 having the mixing time and settling time $30 \mathrm{~min}$ and $120 \mathrm{~min}$ respectively. Low amount of Nitrogen enhances the lipid productivity in the algal biomass. Therefore, Chlorella pyrenoidosa can be an alternative for textile wastewater bioremediation and high biomass can be achieved using urea. The algal biomass produced may be advantageous as fertilizers, feedstock, and production of biofuel. This technology can be used for techno economic wastewater treatment and enhanced biomass production process.

\section{Declarations}

\section{Acknowledgements}

We gratefully acknowledge Head and Mentor, School of Biochemical Engineering, IIT BHU, DST (WOS-B), MHRD and $\mathrm{BHU}$ for providing funds and research facilities, bringing this research work into fruition.

\section{Availability of data and materials}

All the data analyzed during the study have been submitted in the main manuscript so no supportive materials attached separately.

\section{Funding}

This work was supported by Ministry of Science and Technology, Department of Science and Technology, Women Scientist Scheme - B (Ref no. DST/WOS-B/2017/287-AAS)

\section{Author Information}

Affiliations-

Page $11 / 21$ 
School of Biochemical Engineering, IIT BHU, Varanasi - Shubhangi Mishra, Prof. Pradeep Srivastava, Virendra Singh.

Banasthali Vidyapith, Banasthali, Tonk, Rajasthan - Dr. Monika Sharma

\section{Contributions-}

Conceptualization, P.S. and S.M.; Methodology, V.S. and S.M.; Software, V.S.; Validation, M.S. and P.S.; Formal analysis, P.S. and S.M.; Investigation, P.S. and M.S.; Data Curation, M.S.; Resources, P.S. and S.M.; Writing original draft preparation, V.S. and S.M.; Editing and Improvisation, M.S. and P.S. All authors have read and agreed to the published version of the manuscript. The authors read and approved the final manuscript.

\section{Corresponding Author}

Correspondence to Prof. P.K. Srivastava

\section{Competing Interest}

The authors declare that they have no known competing financial interests or personal relationships that could have appeared to influence the work reported in this paper.

\section{Ethics declarations}

All authors of this research paper have directly participated in the planning and execution of this study. Manuscript has not been published elsewhere and that it has not been submitted simultaneously for publication somewhere else.

On behalf of all the authors, I look forward to your positive response.

\section{References}

1. Cai, H., Liang, J., Ning, X. A., Lai, X., \& Li, Y. Algal toxicity induced by effluents from textile-dyeing wastewater treatment plants. Journal of Environmental Sciences, 91, 199-208(2020).

2. Fazal, T., Mushtaq, A., Rehman, F., Khan, A. U., Rashid, N., Farooq, W \& Xu, J. Bioremediation of textile wastewater and successive biodiesel production using microalgae. Renewable and Sustainable Energy Reviews, 82, 31073126(2018).

3. Mahajan, P., Kaushal, J., Upmanyu, A., \& Bhatti, J. Assessment of phytoremediation potential of Chara vulgaris to treat toxic pollutants of textile effluent. Journal of Toxicology, 2019(2019).

4. Mantzavinos D, Psillakis E. Enhancement of biodegradability of industrial wastewaters by chemical oxidation pretreatment. J Chem Technol Biotechnol;79:431-54(2004).

5. Taştan BE, Ertuğrul S, Dönmez G. Effective bioremoval of reactive dye and heavy metals by Aspergillus versicolor. Bioresour Technol;101:870-6(2010).

6. Huang G, Chen F, Wei D, Zhang X, Chen G. Biodiesel production by microalgal biotechnology. Appl Energy;87:3846(2010).

7. Sorokin, C., and J. Myers. A high temperature strain of Chlorella. Science 117:330-331(1953).

8. Ramanan R, Kim BH, Cho DH, Oh HM, Kim HS. Algae-bacteria interactions: evolution, ecology and emerging applications. Biotechnol Adv;34 : pp, 14-29(2016).

9. Subashchandrabose, S.R.; Ramakrishnan, B.; Megharaj, M.; Venkateswarlu, K.; Naidu, R. Mixotrophic cyanobacteria and microalgae as distinctive biological agents for organic pollutant degradation. Environ. Int., 51, 59-72(2013). 
10. Dellamatrice PM, Silva-Stenico ME, Moraes LAB, de, Fiore MF, Monteiro RTR.Degradation of textile dyes by cyanobacteria. Braz J Microbiol;48:25-31(2013).

11. Srinivasan A, Viraraghavan T. Decolorization of dye wastewaters by biosorbents: a review. J Environ Manag;91:1915-29(2010).

12. Logroño W, Pérez M, Urquizo G, Kadier A, Echeverría M, Recalde C, et al. Single chamber microbial fuel cell (SCMFC) with a cathodic microalgal biofilm: a preliminary assessment of the generation of bioelectricity and biodegradation of real dye textile wastewater. Chemosphere;176:378-88(2017).

13. Rahman Bhuiyan MA, Mizanur Rahman M, Shaid A, Bashar MM, Khan MA. Scope of reusing and recycling the textile wastewater after treatment with gamma radiation. J Clean Prod;112:3063-71(2016).

\section{Figures}

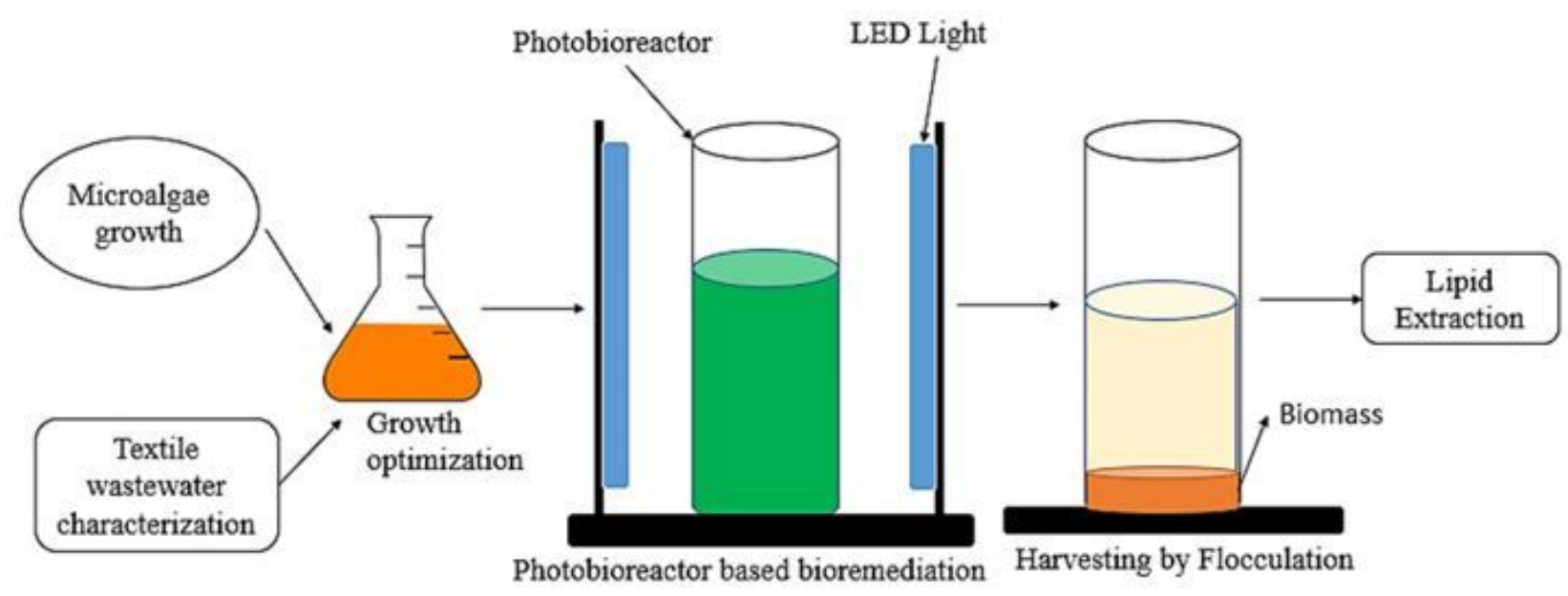

Figure 1

Methodology of Bioremediation of textile wastewater using designed Bubble column tubular Photo-bioreactor. 

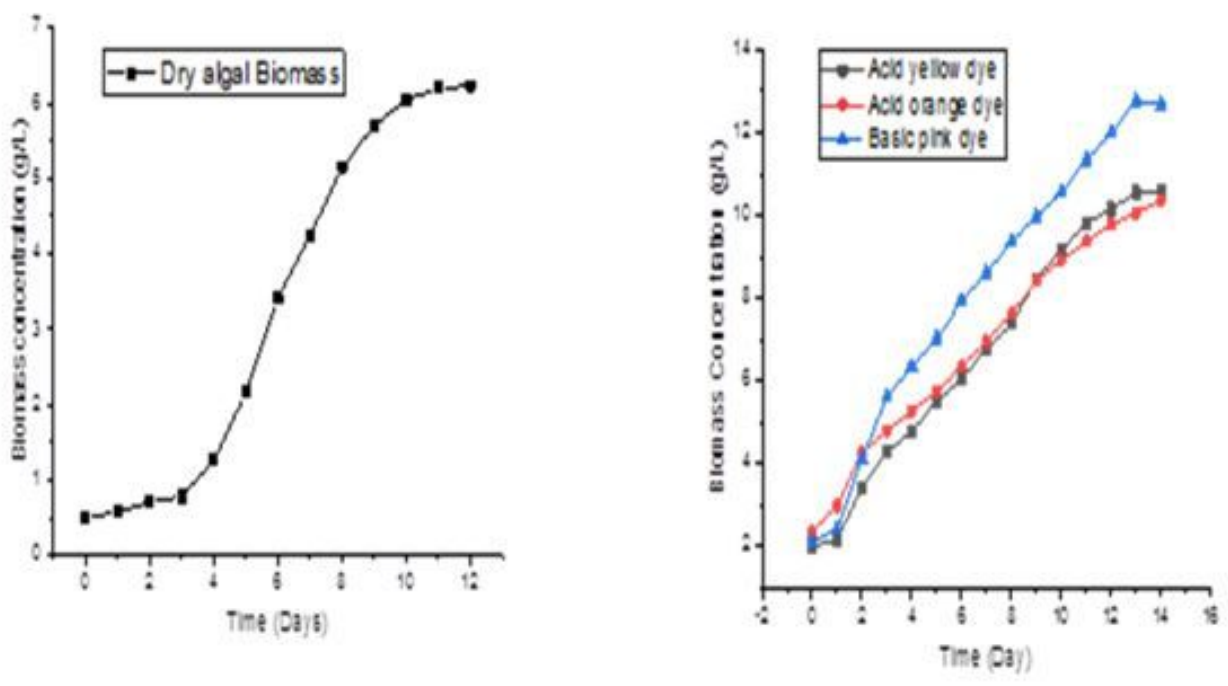

Figure 2(a)

Figure 2(b)
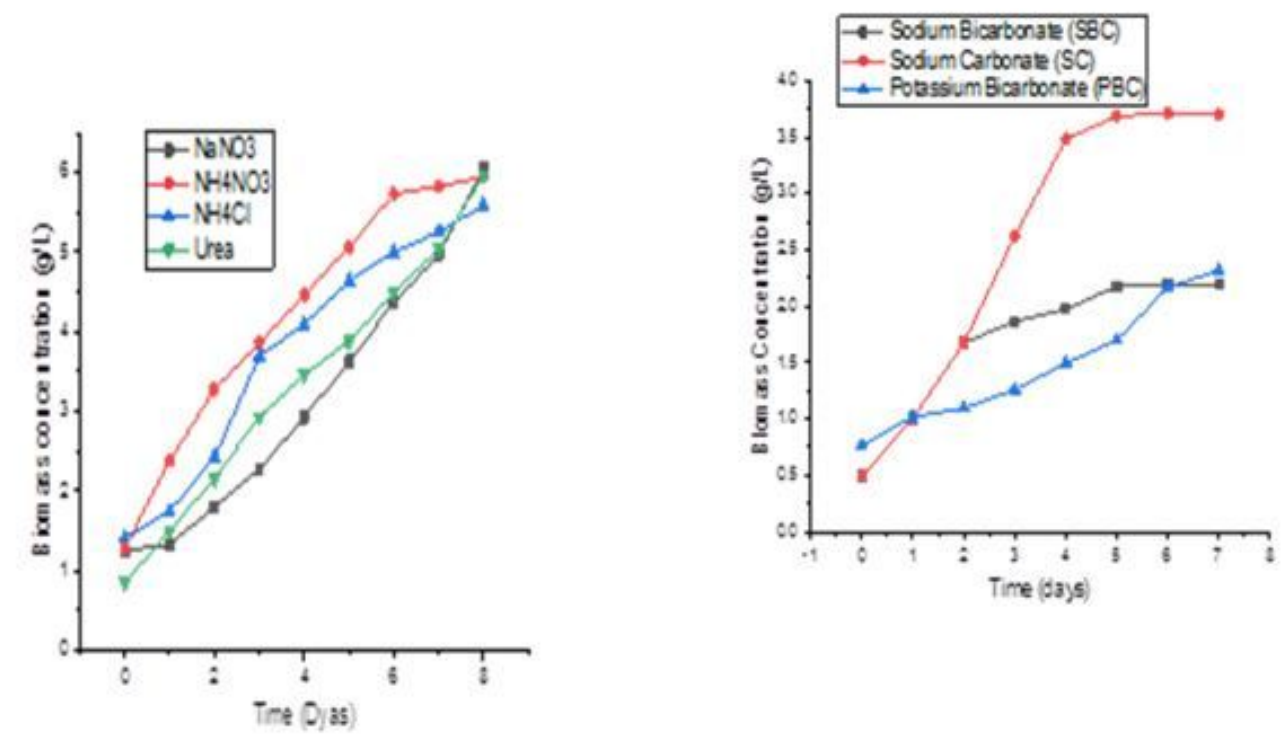

F. axire $2 / c)$

Figure 2(d)

Figure 2

Growth kinetics of Chlorella pyrenoidosa (a) Time course of C. Pyrenoidosa biomass concentration using the Bolds basal media. Growth rate constant is $0.21 \mathrm{~g} /$ Day. (b)Growth curve of Chlorella pyrenoidosa in textile wastewater (Acid yellow 17 dye, Acid orange 7 dye and Basic pink dye) 10\% and BBM 90\% (c) Biomass density in various nitrogen source. (d)Carbon source optimization using three carbon source 


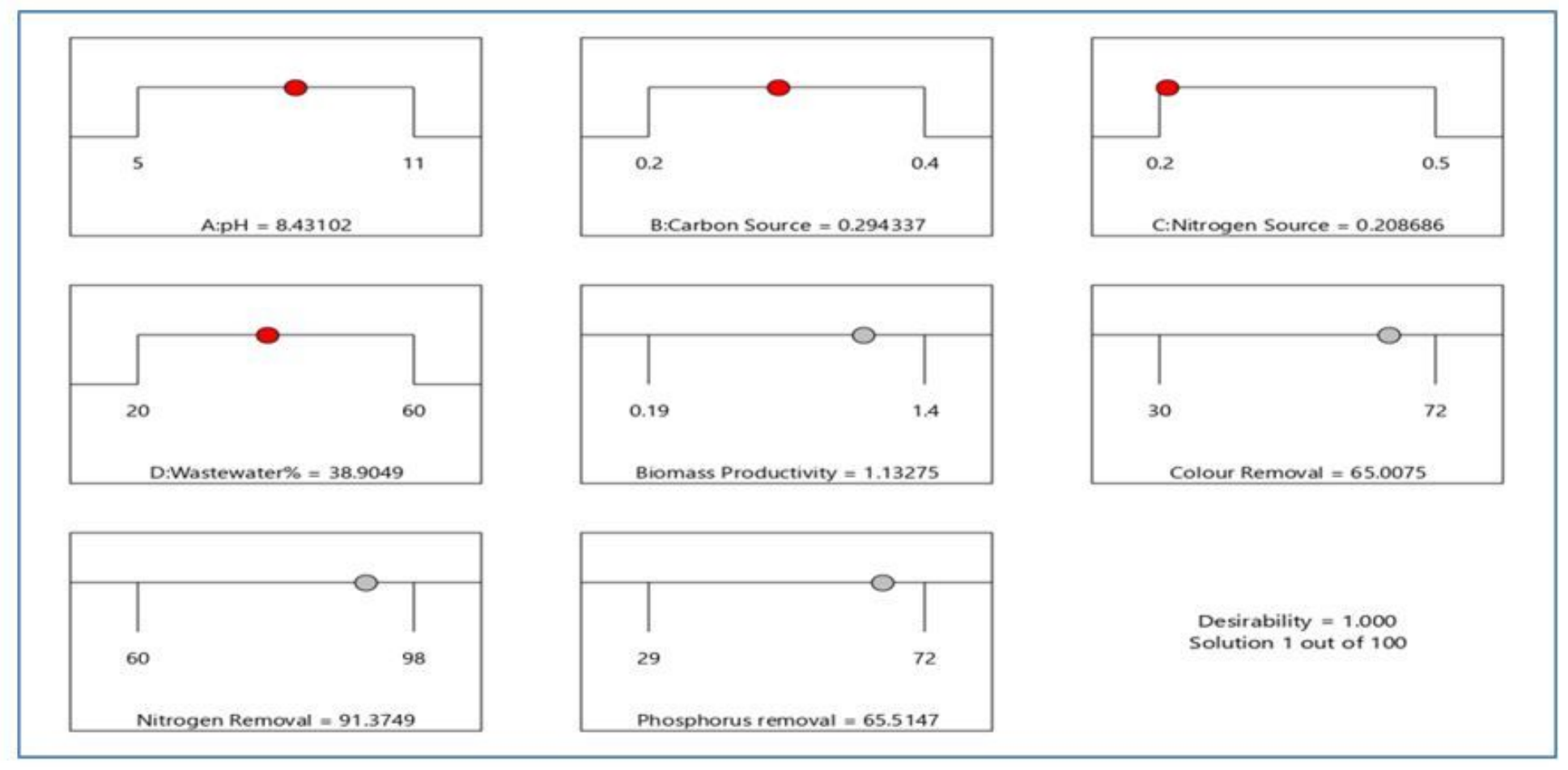

Figure 3

Optimized result from RSM 


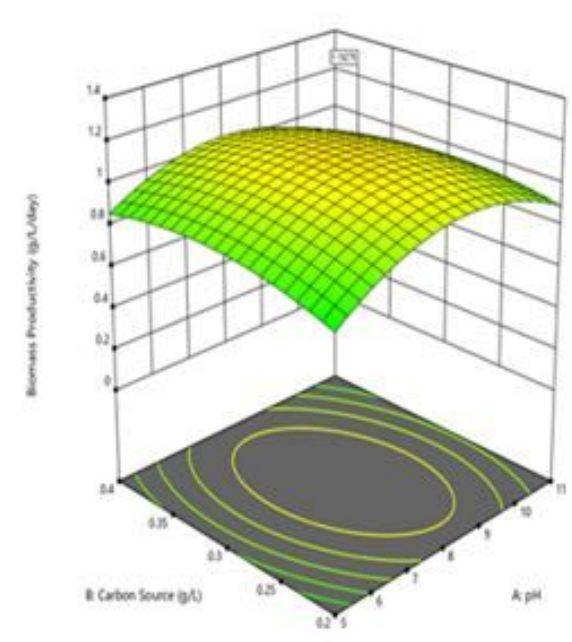

Figure 4(a)

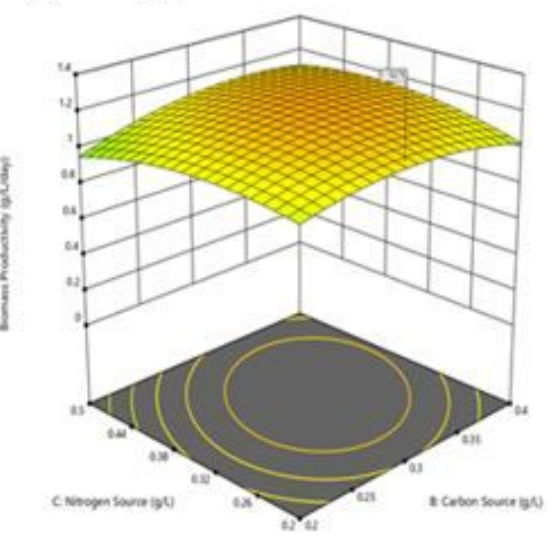

Figure 4(d)

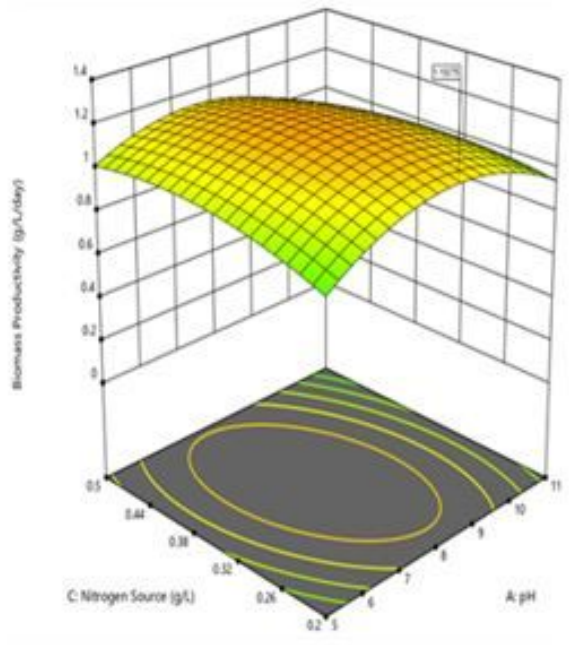

Figure 4(b)

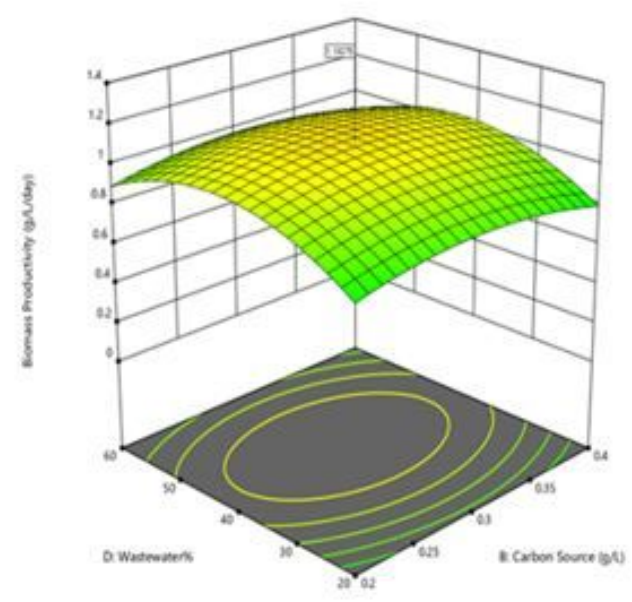

Figure 4(e)

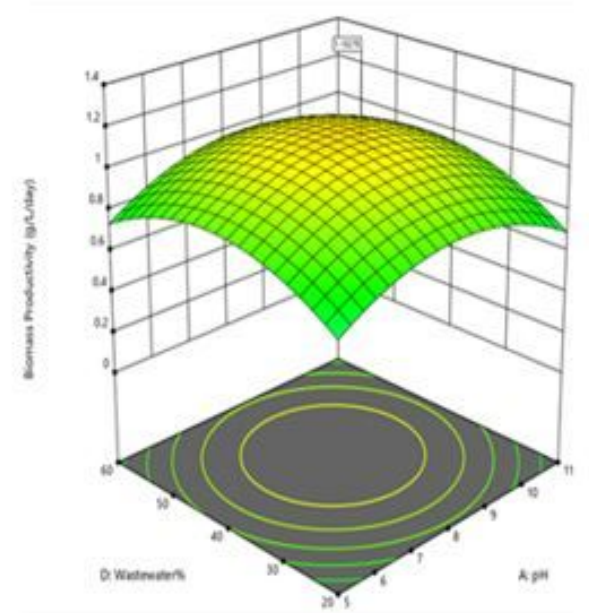

Figure 4(c)

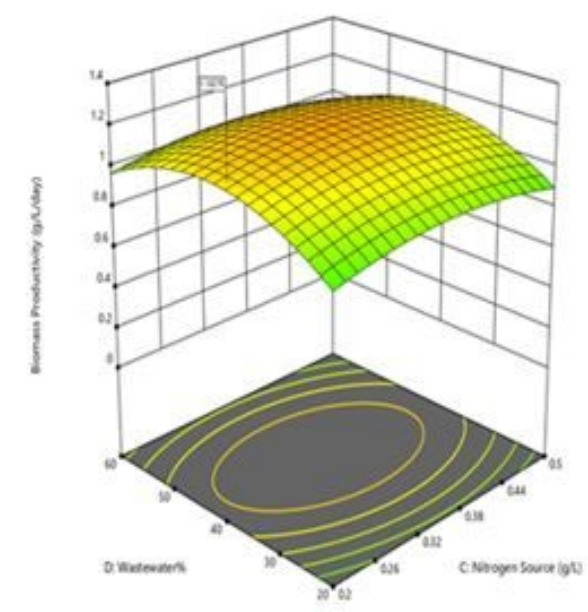

Figure 4(f)

\section{Figure 4}

Surface plot of Biomass productivity includes interaction effect between (a) Carbon source and pH, (b) Nitrogen Source and $\mathrm{pH},(\mathrm{c})$ wastewater\% and $\mathrm{pH},(\mathrm{d})$ Carbon Source and Nitrogen Source, (e) wastewater\% and Carbon source and (f) Wastewater\% and Nitrogen source. 


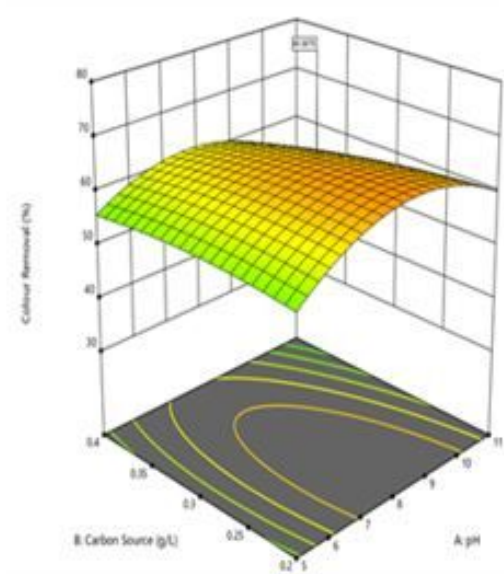

Figure 5(a)

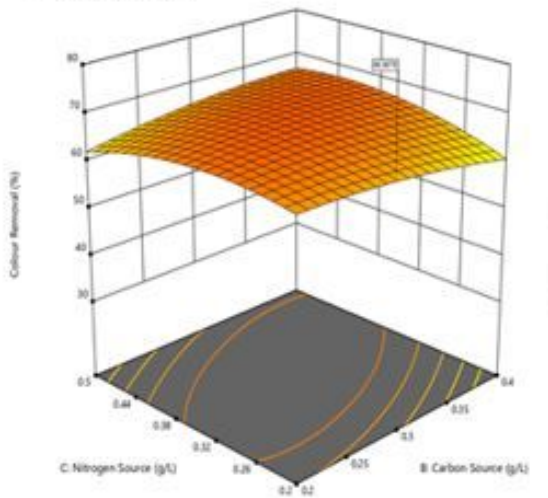

Figure 5(d)

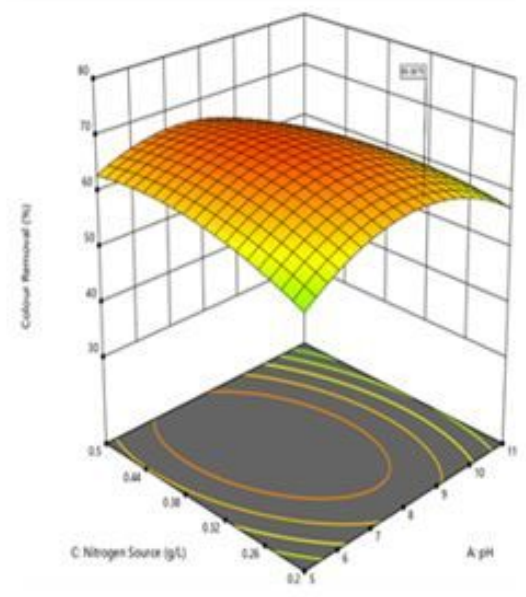

Figure 5(b)

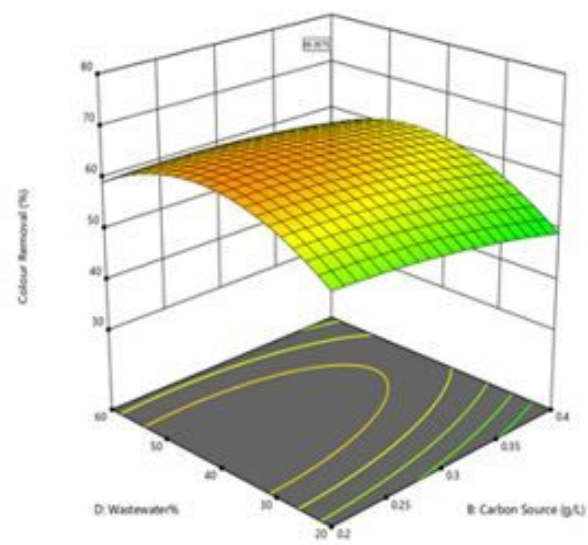

Figure 5(e)

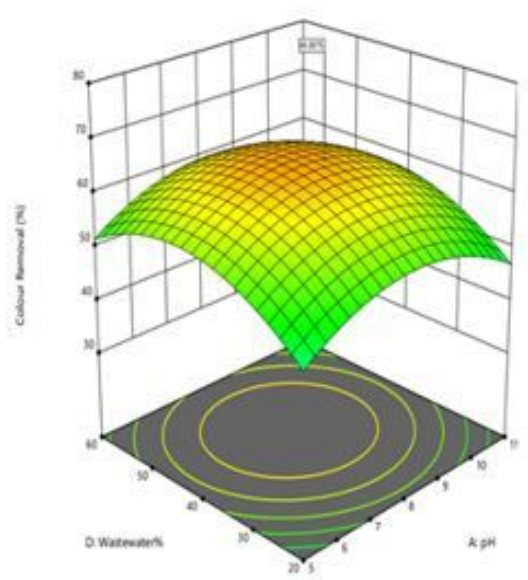

Figure 5(c)

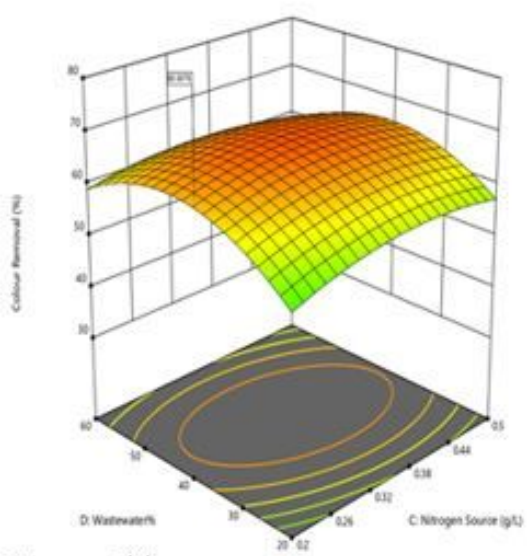

Figure 5(f)

\section{Figure 5}

Surface plot of Colour removal efficiency\% includes interaction effect between (a) Carbon source and $\mathrm{pH}$, (b) $\mathrm{Nitrogen}$ Source and $\mathrm{pH}$, (c) wastewater\% and $\mathrm{pH}$, (d) Carbon Source and Nitrogen Source, (e) wastewater\% and Carbon source and (f) Wastewater\% and Nitrogen source. 


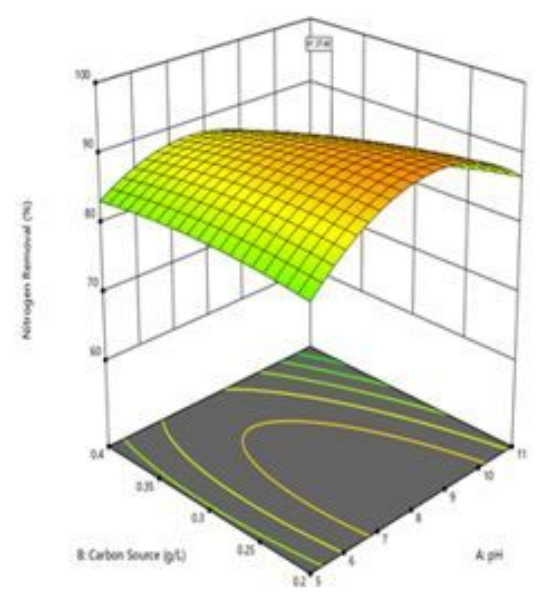

Figure 6(a)

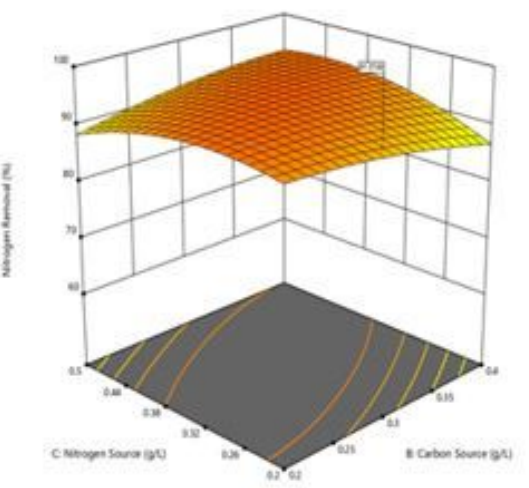

Figure 6(d)

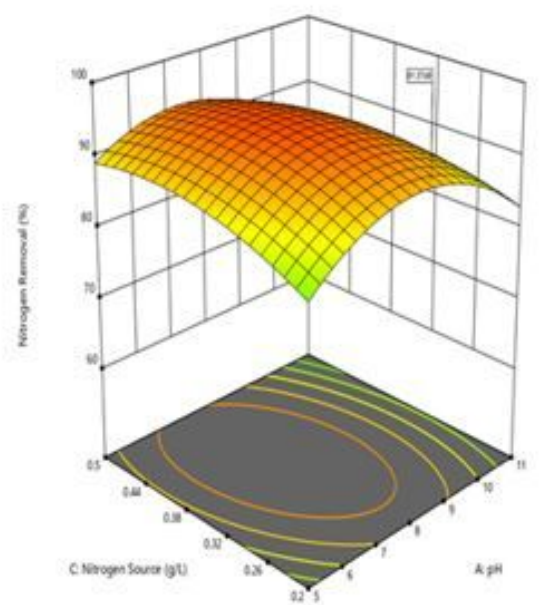

Figure 6(b)

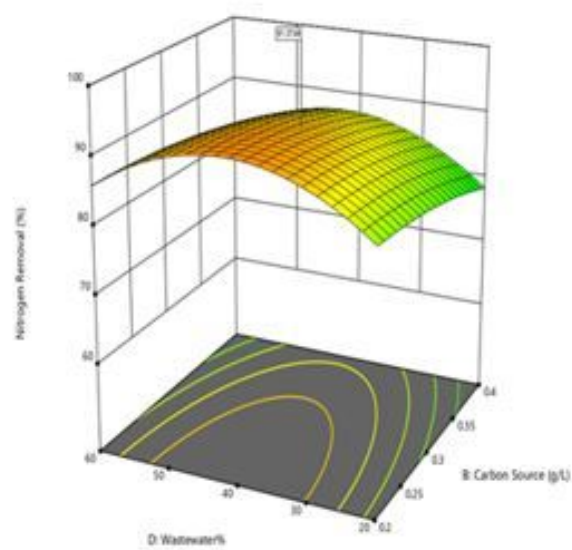

Figure 6(e)

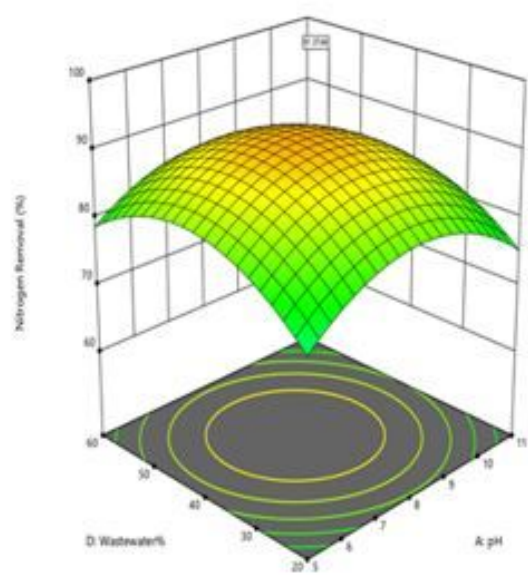

Figure 6(c)

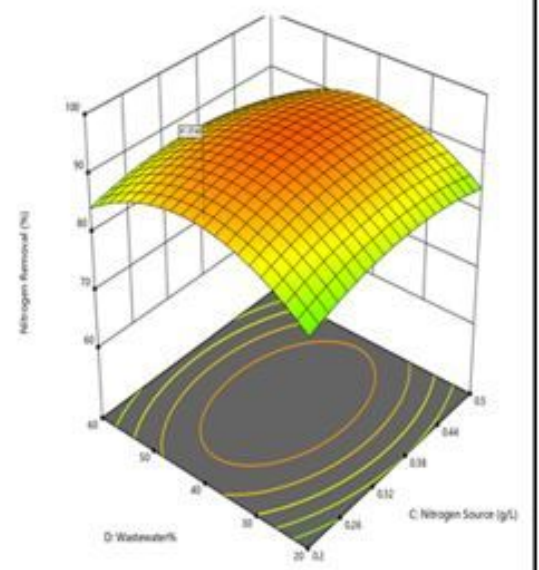

Figure 6(f)

\section{Figure 6}

Surface plot of Nitrogen removal efficiency\% includes interaction effect between (a) Carbon source and pH, (b) Nitrogen Source and $\mathrm{pH},(\mathrm{c})$ wastewater\% and $\mathrm{pH},(\mathrm{d})$ Carbon Source and Nitrogen Source, (e) wastewater\% and Carbon source and (f) Wastewater\% and Nitrogen source. 


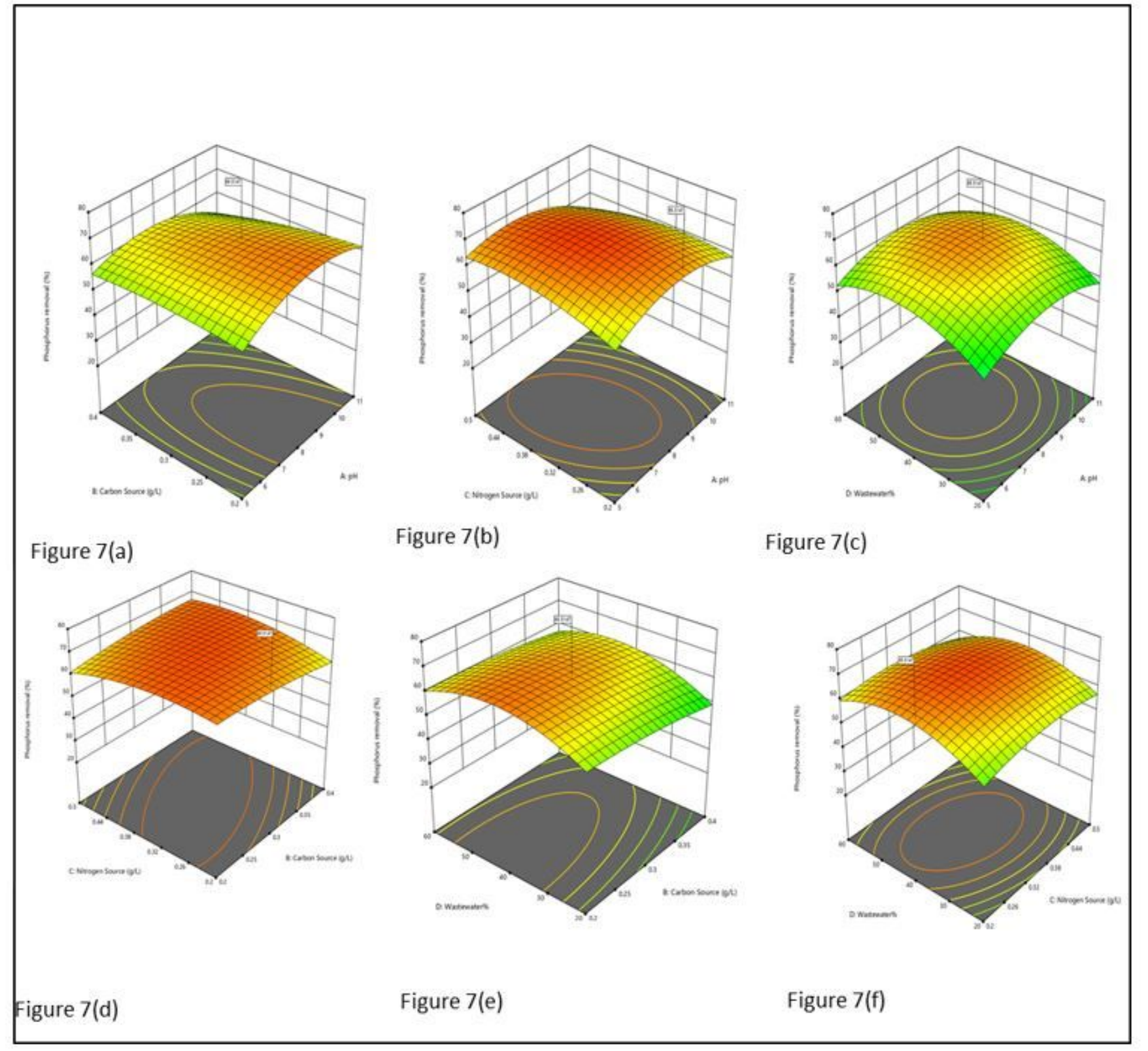

\section{Figure 7}

Surface plot of Phosphorus removal efficiency\% includes interaction effect between (a) Carbon source and $\mathrm{pH}$, (b) Nitrogen Source and pH, (c) wastewater\% and pH, (d) Carbon Source and Nitrogen Source, (e) wastewater\% and Carbon source and (f) Wastewater\% and Nitrogen source. 


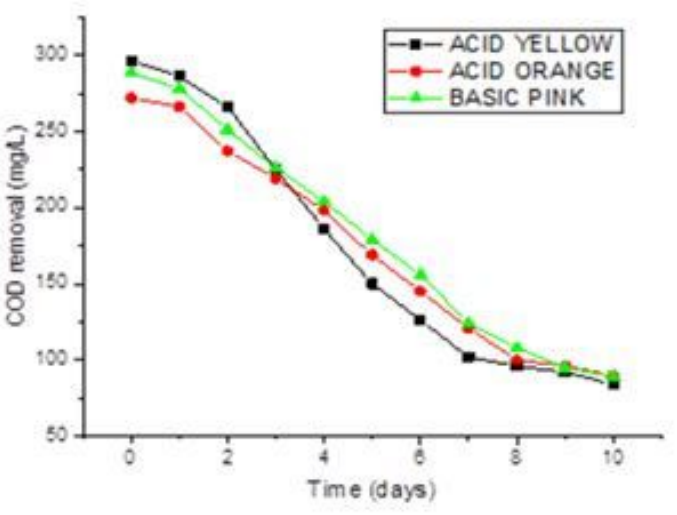

Figure 8(a)

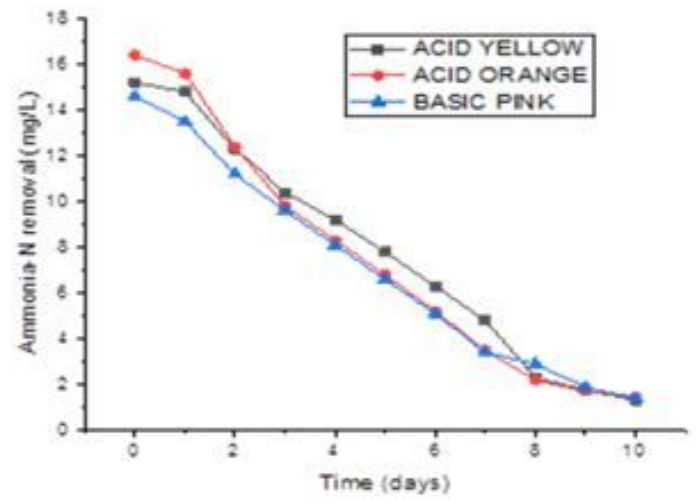

Figure 8(c)

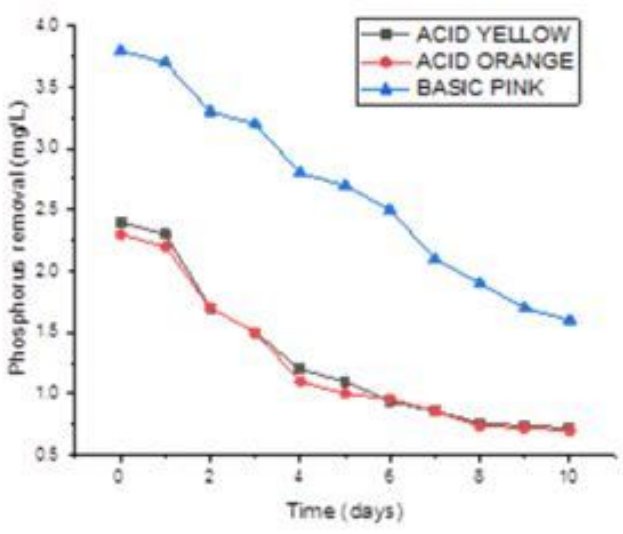

Figure 8(b)

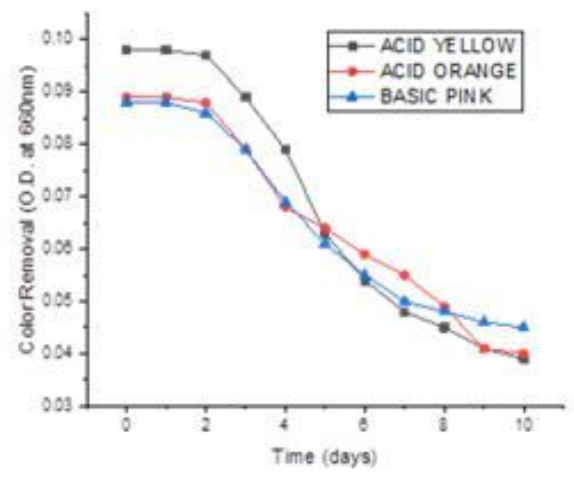

Figure $8(\mathrm{~d})$

Figure 8

Analysis of Pollutant removal in Acid yellow, Acid Orange and Acid Pink dye wastewaters (a) COD removal (b) Phosphorus removal (c) Ammonia removal (d) Color removal. 


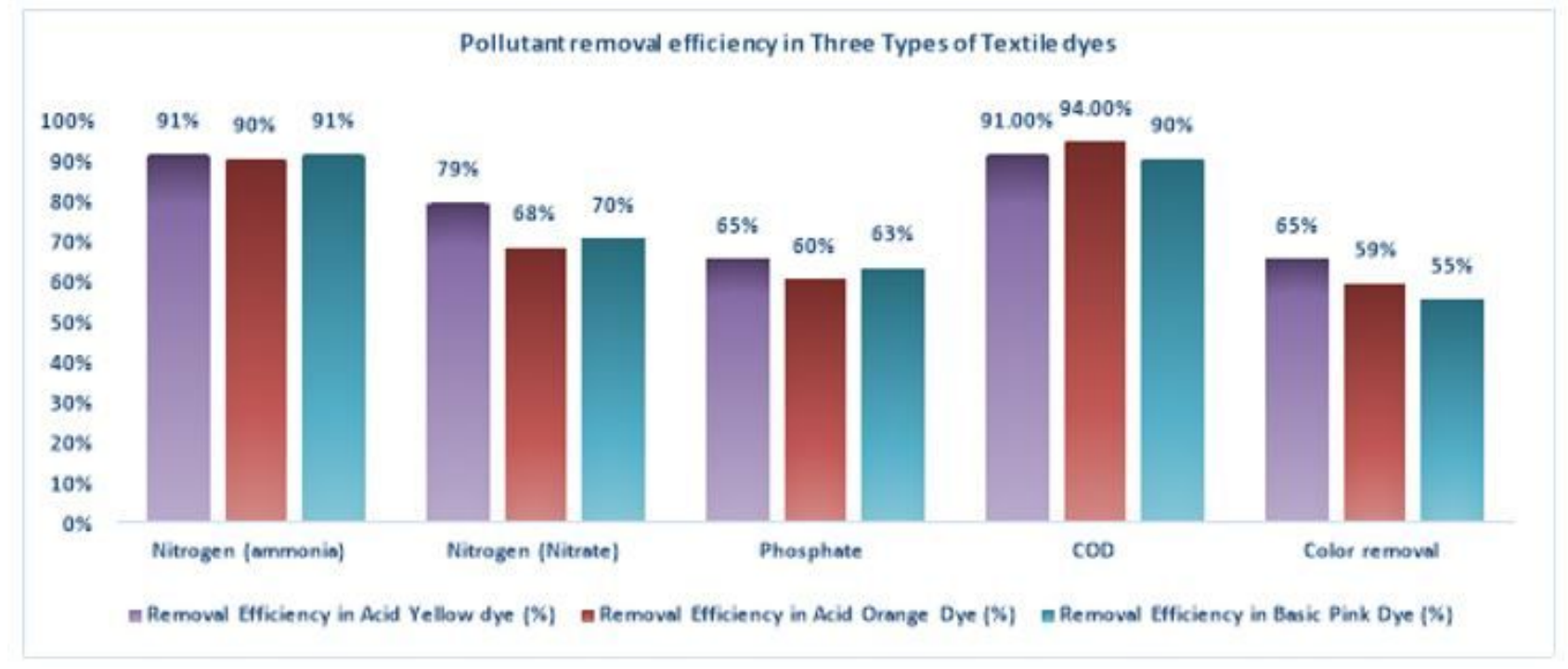

\section{Figure 9}

Comparative Analysis of Efficiency of Pollutant removal in Acid yellow, Acid Orange and Acid Pink dye wastewaters for nitrogen (ammonia) removal, Nitrogen (nitrate) removal, COD removal, colour removal, and phosphorus removal. A very little variation in nitrogen (ammonia) removal efficiency in acid yellow dye containing textile wastewater (91 $\pm 3 \%$ ), acid orange dye containing textile wastewater $(90 \pm 3 \%)$, and basic pink dye containing textile wastewater $(91 \pm 1 \%)$. A small variation found in nitrogen (Nitrate) removal efficiency in acid yellow dye containing textile wastewater (79 $\pm 2 \%)$, acid orange dye containing textile wastewater $(68 \pm 3 \%)$, and basic pink dye containing textile wastewater $(70 \pm 4 \%)$. 